\section{Microbial deterioration of white variety sweet potato (Ipomoea batatas) under different storage structures}

\author{
Charles Tortoe, Mary Obodai, \\ Wisdom Amoa-Awua \\ CSIR Food Research Institute, Accra, \\ Ghana
}

\begin{abstract}
Post-harvest protection of white variety sweet potato (Ipomoea batatas) has been dealt with rarely in the past, although it is comparatively easy to grow and has high consumer acceptability in Ghana. Microbial deterioration of sweet potato roots stored in three different storage structures was studied. The sweet potato roots initially cured for 7 and 14 days were stored in traditional, pit, and clamp storage structures for a maximum of 28 days. For the 7 days-cured sweet potato roots, the bacteria population in the three different storage structures increased by 1.2-2.3 log cfu/g whereas for the 14 days-cured roots, the bacteria population was 0.1-1.0 log cfu/g within 28 days of storage. The fungal population in the 14 days-cured sweet potato roots was higher than in the 7 days-cured sweet potato roots by 0.6 $1.6 \log \mathrm{cfu} / \mathrm{g}$ for 28 days of storage. For both the 7 and 14 days-cured sweet potato roots, the sweet potato roots stored for 28 days in the three different storage structures had a higher microbial count compared to the sweet potato roots stored for 14 days. Aspergillus flavus was the most dominant fungal species occurring in all of the three different storage structures followed by A. niger, Rhizopus stolonifer, Trichoderma viride, Fusarium oxysporum, Penicillium digitatum, Cladosporium herbarum, and Aspergillus ochraceus, in that order.
\end{abstract}

\section{Introduction}

Sweet potato (Ipomoea batatas (L.) Lam) belongs to the Convolvulaceae family and is a root crop cultivated in many countries including Sub-Saharan Africa. It is among the world's most important, versatile, and underutilized food crops that rank fourth among the food crops after rice, potato, and wheat and seventh in terms of total production. ${ }^{1-3}$ Sweet potato is grown generally for its storage roots, which are eaten fresh, steamed, or boiled. Sometimes the leaves are eaten as vegetables, the vines are fed to livestock, and the storage roots are processed into flour for use during the lean season.

It is estimated that in the tropics each year between $25 \%$ and $40 \%$ of stored agricultural products are lost because of inadequate farm and village-level storage. ${ }^{4}$ Quantitative and qualitative losses or a combination of both arising from post-harvest storage result from physical, physiological, or pathological factors or various combinations of these factors. ${ }^{5}$ After harvesting, sweet potato roots are perishable products and are subject to high losses during transportation, storage, and selling. The thin skin of the sweet potato root is damaged easily during harvest and post-harvest handling. In addition its high water content makes storage difficult and microorganisms easily attack the roots, resulting in high losses. Normally, the fungi causing rot in sweet potato are lesion pathogens. The rot changes the consistency of flour from the roots making them no longer suitable for consumption or causing a considerable loss in market value. ${ }^{6}$

Under a controlled environment, sweet potato roots can be stored for several months. Picha ${ }^{7}$ stored sweet potato roots at $13-15^{\circ} \mathrm{C}$ and high humidity (90-95\% relative humidity) for a year in the USA. However, the application of a temperature controlled environment for storing sweet potato roots is not economically feasible in tropical developing countries. Interestingly, in the absence of temperature control, Hall and Devereau ${ }^{8}$ and Van Oirschot et al. ${ }^{9}$ reported a duration of 3-4 months after careful selection of the roots stored in traditional structures, pits, or clamps in which high humidity (90-95\% relative humidity) was maintained. In other studies to prolong the storage of the roots, they were cured to protect them from storage disease and excessive shrinkage. ${ }^{10,11}$ Curing allows injured roots marked by high water content to heal. Noticeable changes occurring are desiccation of several layers of the outermost parenchymal cells exposed to air on wounding. It has been shown that beneath the dissociated cells is a subsequent deposition of a polymeric material in the parenchymal cells. ${ }^{10}$ Thompson ${ }^{11}$ showed that the percentage weight loss during storage of cured and uncured roots in the West Indies for 113 days was $17 \%$ and $43 \%$, respectively.

Traditional storage methods have recorded heavy storage losses owing to sprouting, rodent destruction, and insect and microbial damage. Although sweet potato is comparatively easy to grow and has high consumer acceptability, its post-harvest protection has been dealt with rarely in the past. This particu larly applies to storage by small-scale farmers, although this group of producers is the one that cultivates and stores roots and tubers most, especially in Africa. In addition, varieties among sweet potato may have different storage requirements. However, the literature is
Correspondence: Charles Tortoe, CSIR Food Research Institute, P.0. Box M20, Accra, Ghana. E-mail: ctortoe@fri.csir.org.gh

Key words: sweet potato, storage structures, traditional, pit, clamp, microorganism.

Received for publication: 5 February 2010.

Revision received: 22 April 2010.

Accepted for publication: 22 April 2010.

This work is licensed under a Creative Commons Attribution 3.0 License (by-nc 3.0).

(C) Copyright C. Tortoe et al., 2010

Licensee PAGEPress, Italy

International Journal of Plant Biology 2010; 1:e10 doi:10.4081/pb.2010.e10

limited on the microbial deterioration of the white variety sweet potato stored under traditional, pit, and clamp storage structures. The white variety sweet potato is the largely cultivated variety in Ghana. This study establishes the spoilage microbes, with emphasis on fungi, responsible for storage losses of the white variety sweet potato roots under traditional, pit, and clamp storage structures.

\section{Materials and Methods}

\section{Plant material and curing treatment}

White variety sweet potato roots were obtained from the Crop Research Institute, Kumasi, in the Ashanti Region of Ghana. Two batches, each of $600 \mathrm{~kg}$ of wholesome sweet potato roots were piled and covered with jute sacks, and cured at $30-35^{\circ} \mathrm{C}$ and relative humidity of $80-90 \%$ for 7 and 14 days.

\section{Storage structures}

Three storage structures: traditional, pit, and clamp were used in this study. Two of each storage structure were constructed on a welldrained ground at the premises of the Food Research Institute, Accra. The traditional storage structure consisted of a cylindrical hole $(1.0 \times 1.0 \times 1.0 \mathrm{~m})$ dug in the dry ground and lined on the floor and walls with $20 \mathrm{~kg}$ of dry grass. The grass was used for cushioning and absorbing excess moisture. The traditional storage structure was constructed in raised ground under a tree to prevent flooding and excessive sunshine. Cured sweet potato roots were placed carefully in the hole, and closed with grass and soil to normal ground level.

The pit is an improvement on the traditional storage structure. It consisted of a cylindrical hole $(1.0 \times 1.0 \times 1.0 \mathrm{~m})$ dug in dry ground and lined with $20 \mathrm{~kg}$ of dry grass on the floor and walls of the hole. A sloping thatched roof was 
constructed over the pit to prevent rain getting into the pit and avoid much exposure to sunshine. A small space was left between the base level of the thatched roof and the ground to allow for ventilation. The cured sweet potato roots were placed carefully in the pit on the dry grass and covered with more dry grass.

The clamp storage structure consisted of a circular bed of dry grass, $20 \mathrm{~cm}$ thick, made on a $25 \mathrm{~cm}$ raised flat mound of earth, surrounded by a concrete wall $30 \mathrm{~cm}$ above ground level. A hut with a sloping thatched roof, supported by wood and wire mesh that prevented rodents from entering, was built on the concrete wall. The thatched roof was provided to prevent too much exposure to sunshine or damage by heavy rains. Cured sweet potato roots were placed carefully on top of the circular bed of dry grass and covered with more grass. This protects the sweet potato roots from drying out.

Wholesome sweet potato roots (140 kg), after being cured for 7 and 14 days, were placed in each of the traditional, pit, and clamp storage structures.

\section{Assessment of fungal, insect, and rodent damage of sweet potato roots}

Fortnightly after storage, $20 \mathrm{~kg}$ of the samples from each of the three storage structures/ treatments and two replicates were removed randomly, kept separately, and assessed physically for fungal-infected, insect- and rodentdamaged, wholesome and sprouted sweet potato roots, based on the following descriptions. i) Fungal infection: presence of dirty white fluffy mycelium spreading on the outer covering of the root, and of wet and dry rot on the root. ii) Insect and rodent damage: presence of insects and rodent bites on roots, and the roots are aesthetically unacceptable. iii) Wholesome: roots with perfect rind, rind intact, no blemish on the rind, smooth outer covering of the roots, and roots are in excellent condition. iv) Sprouted: root rind is broken, 13 sprouts on the root, $0.1 \mathrm{~cm}$ to $3.0 \mathrm{~cm}$ in length, occurring at one end of root. This descriptive procedure was followed for a period of 84 days.

\section{Microbial assessment}

Samples $(20 \mathrm{~kg})$ were withdrawn from each of the three treatments, with two replicates, after 14 and 28 days of storage and microbial determination performed. Infected sweet potato roots (10 g), physically assessed as presented above, were placed in sterile $250 \mathrm{~mL}$ Erlenmeyer flasks containing $100 \mathrm{~mL}$ of $0.1 \%$ peptone. The mixture was swivelled at 140 $\mathrm{rev} / \mathrm{min}$ for $15 \mathrm{~min}$. Aliquots of the suspension $(0.1 \mathrm{~mL})$ were transferred into sterile testtubes containing $9 \mathrm{~mL}$ of $0.1 \%$ peptone, and serially diluted up to $1: 5$. In order to estimate

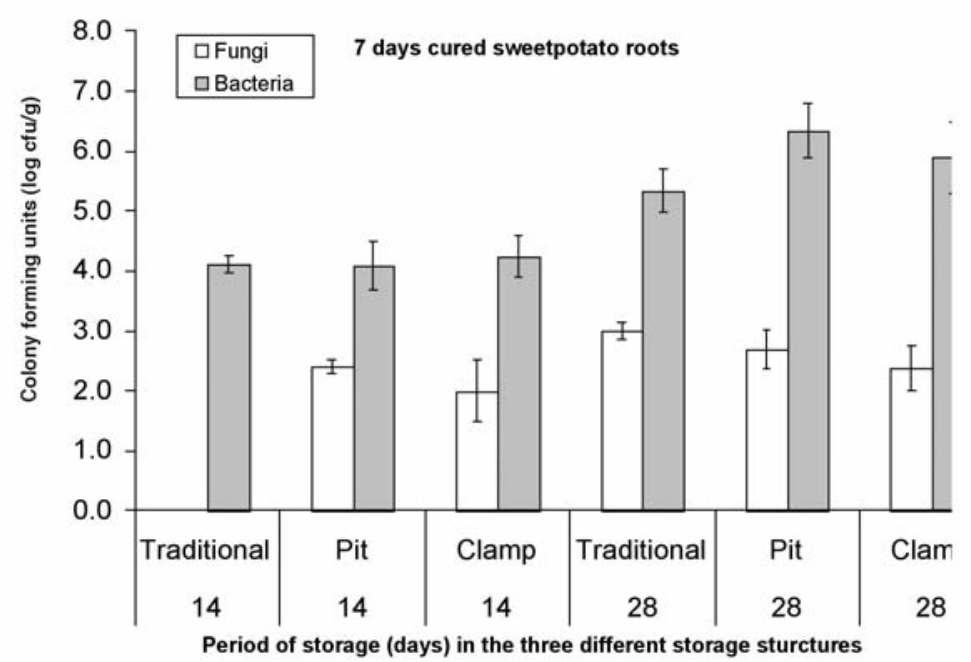

Figure 1. Comparison of fungal and bacterial populations isolated from 7 days-cured sweet potato roots stored for 14 and 28 days under traditional, pit, and clamp storage structures.

the mesophilic fungal populations, a $1.0 \mathrm{~mL}$ aliquot of each dilution, in duplicate, was poured into sterile Petri dishes containing 20 $\mathrm{mL}$ of malt extract agar. The Petri plates were incubated at $30^{\circ} \mathrm{C}$ for 7 days. The mycoflora were identified using their morphological color and colony characteristics as outlined by Samson et al. ${ }^{12}$ Bacterial populations were estimated on plate count agar at $37^{\circ} \mathrm{C}$ after $24 \mathrm{~h}$ of incubation. Total counts were expressed as colony-forming units (log cfu/g) of the sample. ${ }^{13}$ Results reported are based on experiments conducted in triplicates.

\section{Statistical analysis}

Duplicate experiments were conducted from the three different storage structures and two curing processes for the storage of white variety sweet potato to obtain mean results. The data were statistically analyzed using Statgraphics Plus Version 3.0 (Graphics Software System, STCC, USA). Mean separation was carried out using Duncan's Multiple Range Test (DMRT) defined at $\mathrm{P}<0.05$.

\section{Results}

\section{Microbial assessment}

For the 7 day-cured sweet potato roots, the bacterial population in the traditional, pit, and clamp storage structures increased by 1.2-2.3 $\log \mathrm{cfu} / \mathrm{g}$ from 14 to 28 days of storage. Similar results were obtained for the 14 days-cured sweet potato roots; however, the increase was by $0.1-1.0 \log \mathrm{cfu} / \mathrm{g}$ from 14 to 28 days of storage (Figures 1 and 2). The fungal population in the 14 days-cured sweet potato roots was higher than in the 7 days-cured sweet potato roots by $0.6-1.6 \log \mathrm{c} / \mathrm{fu}$ after 28 days of storage (Figures 1 and 2). In both the 7 and 14 dayscured roots, 28 days of storage resulted in a higher microbial count compared to 14 days of storage (Figures 1 and 2). Comparing microbial counts in the traditional, pit, and clamp storage structures, bacteria counts were higher than fungal counts (Figures 1 and 2).

Fungal loads associated with the 7 day-cured sweet potato roots in the traditional, pit, and clamp storage structures after 28 days of storage were significantly higher $(\mathrm{P}<0.05)$ than for 14 days of storage in the three storage structures (Figure 1). The fungal loads of the 7 day-cured sweet potato roots stored for 28 days in the traditional storage structure were significantly higher $(\mathrm{P}<0.05)$, followed by pit and clamp storage structures in a decreasing order, as shown in Figure 1. The bacterial loads for the 7 day-cured sweet potato roots stored for 28 days were significantly higher than those stored for 14 days in all three storage structures. Although the bacterial loads after 28 days of storage were significantly different $(\mathrm{P}<0.05)$ within the three storage structures, the bacterial loads after 14 days of storage for traditional, pit, and clamp structures were not significantly different $(\mathrm{P}>0.05)$, as presented in Figure 1. The sweet potato roots in the pit storage structure after 28 days of storage recorded the highest bacteria counts, followed by the traditional and the clamp storage structures in a decreasing order (Figure 1).

Figure 2 shows that for the 14 days-cured sweet potato roots stored in the traditional, pit, and clamp storage structures, there were significant differences $(\mathrm{P}<0.05)$ in fungal loads in those roots stored for 28 and for 14 days. 
The bacteria counts in the 14 day-cured sweet potato roots stored in the traditional and clamp storage structures were higher than for the pit storage structure in both those stored for 14 and for 28 days, as depicted in Figure 2. Although within the bacteria population for the 14 days-cured sweet potato there were not significant differences $(\mathrm{P}>0.05)$ except for the pit storage structure for 14 days of storage, the bacteria population was significantly different $(\mathrm{P}<0.05)$ from the fungal loads, with a higher bacteria population in all three storage structures (Figure 2). A similar observation occurred in the 7 days-cured sweet potato roots, with a significantly higher bacteria population compared to fungal loads in all three storage structures, as presented in Figure 1.

The phenology of the fungal species isolated from sweet potato roots cured for 7 days and stored for 14 days comprised three fungal species belonging to three genera: Cladosporium, Fusarium, and Rhizopus, whereas that of the sweet potato roots stored for 28 days consisted of six fungal species belonging to five genera, namely Aspergillus, Fusarium, Penicillium, Rhizopus, and Trichoderma (Table 1). Aspergillus species predominated in all three different storage structures for both 7 and 14 days-cured sweet potato roots. A. flavus occurred in all three storage structures followed by $A$. niger, $R$. stolonifer, T. viride, $F$. oxysporum, $P$. digitatum, $C$. Herbarum, and $A$. Ochraceus, in that order (Table 1). $C$. Herbarum, which appeared in the 7 and 14 days-cured sweet potato roots stored for 14 days in clamp and pit storage structures, was absent in the other structures and disappeared after 28 days of storage (Table 1).

The percentage occurrence of the different species of fungi differed among the three different storage structures (Table 2). This is seen in the occurrence of $A$. flavus. A. flavus isolated from the 14 days-cured roots was $10 \%$ more than $A$. flavus isolated from the 7 dayscured roots in the pit storage structure after 28 days of storage. Occurrence of $A$. flavus in the traditional storage structure with the 14 dayscured roots was $20 \%$ more than A. flavus isolated from the 7 days-cured roots stored for a period of 28 days. However, in the clamp storage structure the occurrence of $A$. flavus isolated from the 7 days-cured roots was $35.8 \%$ more than in the 14 days-cured roots stored for a period of 28 days (Table 2). The predominant fungal species from all the treatments over the 28 days of storage were $A$. flavus and A. niger.

\section{Discussion}

In studies conducted by Wills et al. ${ }^{14}$ the authors reported that mechanical damage dur-

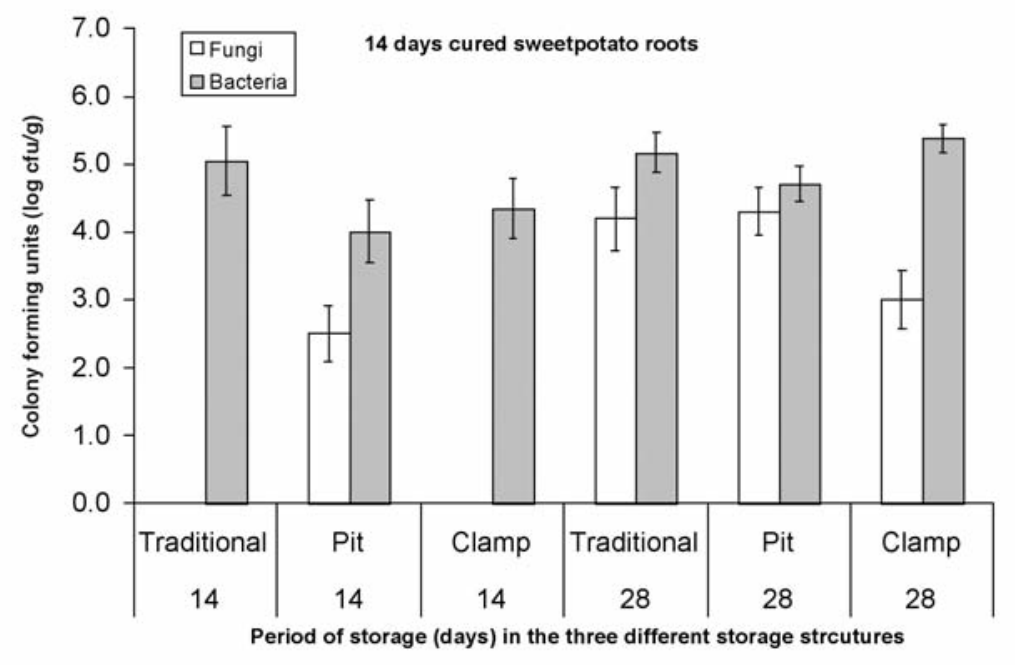

Figure 2. Comparison of fungal and bacterial populations isolated from 14 days-cured sweet potato roots stored for 14 and 28 days under traditional, pit, and clamp storage structures.

Table 1. Fungal profile in three different storage structures for 7 and 14 days-cured sweet potato roots stored for 14 and 28 days.

\begin{tabular}{|c|c|c|c|c|}
\hline $\begin{array}{l}\text { Period of } \\
\text { curing } \\
\text { (days) }\end{array}$ & $\begin{array}{l}\text { Period of } \\
\text { storage } \\
\text { (days) }\end{array}$ & $\begin{array}{l}\text { Fungal profil } \\
\text { Traditional }\end{array}$ & $\begin{array}{l}\text { ee different } \\
\text { Pit }\end{array}$ & $\begin{array}{l}\text { structures } \\
\text { Clamp }\end{array}$ \\
\hline 7 & 14 & & R. stolonifer & $\begin{array}{l}\text { C. herbarum } \\
\text { F. oxysporum }\end{array}$ \\
\hline 7 & 28 & $\begin{array}{l}\text { A. flavus } \\
\text { A. niger } \\
\text { F. oxysporum } \\
\text { P. digitatum } \\
\text { R. stolonifer } \\
\text { T. viride }\end{array}$ & $\begin{array}{l}\text { A. flavus } \\
\text { A. niger } \\
\text { F. oxysporum } \\
\text { R. stolonifer } \\
\text { T. viride }\end{array}$ & $\begin{array}{l}\text { A. flavus } \\
\text { A. niger } \\
\text { F. oxysporum } \\
\text { P. digitatum } \\
\text { R. stolonifer } \\
\text { T. viride }\end{array}$ \\
\hline 14 & 14 & $\mathrm{n} / \mathrm{a}$ & C. herbarum & $\mathrm{n} / \mathrm{a}$ \\
\hline (U) & 28 & $\begin{array}{l}\text { A. flavus } \\
\text { A. niger } \\
\text { A. ochraceus } \\
\text { R. stolonifer }\end{array}$ & $\begin{array}{l}\text { A. flavus } \\
\text { F. oxysporum } \\
\text { T. viride }\end{array}$ & $\begin{array}{l}\text { A. flavus } \\
\text { A. niger } \\
\text { R. stolonifer }\end{array}$ \\
\hline
\end{tabular}

n/a: species not available

Table 2. Percentage occurrence of the fungal species in the three different storage structures for 7 and 14 days-cured sweet potato roots stored for 28 days.

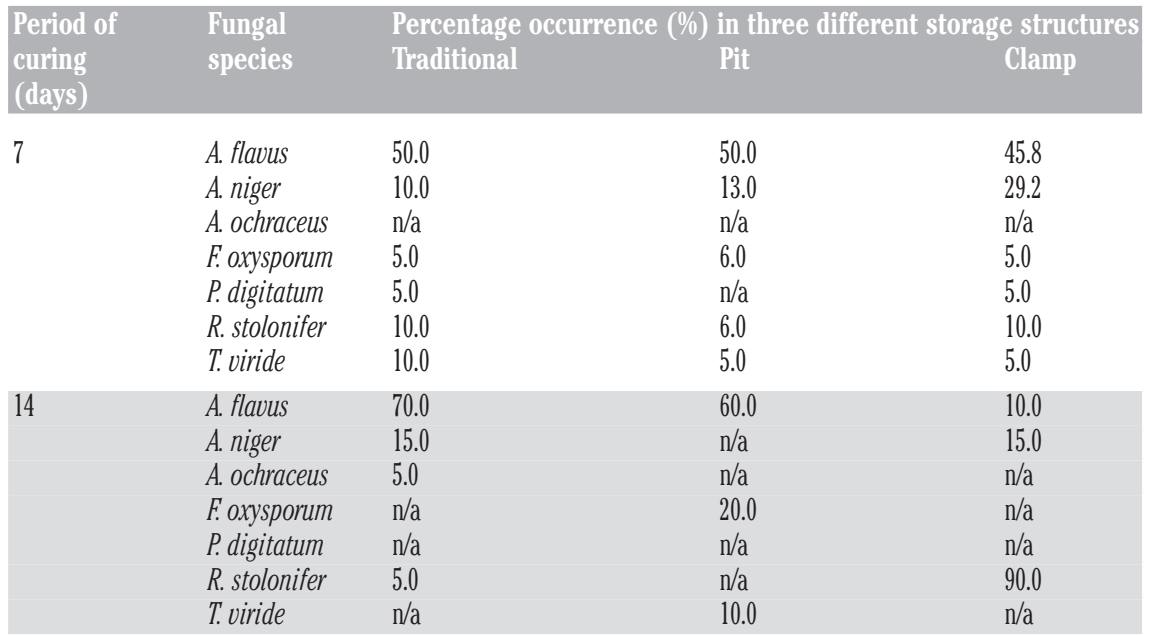

n/a: species not available 
ing harvest, transportation, and storage is detrimental to the shelf-life of fresh produce, as the damage area forms an avenue for moisture loss and an entrance for microorganisms. The thin skin of sweet potato roots is easily damaged during harvest and post-harvest handling, leaving the crop highly perishable., The wounds in sweet potato can cure excellently when the roots are exposed to temperatures of $28-30^{\circ} \mathrm{C}$ and relative humidity greater than $85 \%{ }^{15}$ Hayma $^{4}$ reported temperatures of $25-35^{\circ} \mathrm{C}$ and relative humidity of $85-90 \%$, which are within the range used in our study. The process of "curing" to promote healing of sweet potato is similar to that used in other roots and tubers such as cassava and yam. ${ }^{16-18}$ According to Hayma, ${ }^{4}$ during the process of curing of roots and tubers a layer of cork cells, a few cell layers thick, is formed around the roots and tubers. This layer greatly reduces the desiccation process and largely prevents infection by bacteria and fungi. Demeaux and Vivier ${ }^{10}$ reported that during the curing process of roots and tubers, several layers of the outermost parenchymal cells exposed to air on wounding desiccate with subsequent deposition of a polymeric material in the parenchymal cells beneath the desiccated cells.

The higher microbial counts for the 14 dayscured roots are an indication of their high susceptibility to microbial attack. This is because most of the roots' carbohydrate has been utilized for energy during which process carbon dioxide and water are emitted to the environment as gases. ${ }^{19}$ In the tropics, increased metabolic rates are expected, which is strongly dependent on the temperature and moisture content of the product. As the storage period was increased from 14 to 28 days, greater numbers of fungi and bacteria were present in all three storage structures. However, the lowest microbial counts were recorded in the clamp storage structure followed by the pit and traditional storage structures. This was a result of the close contact of the stored roots in the traditional storage structure to soil fungi and bacteria. Because of the high moisture content of the sweet potato roots, they are easily attacked by microbes. The fungi causing "dry" or "soft" rot normally are lesion pathogens that penetrate the sweet potato roots through lesions, cuts, holes bored by nematodes, or where rodents have bitten the roots..$^{20}$ In the clamp storage structure, sweet potato roots stored are kept away from direct contact with the soil thus reducing the rate of microbial infection.

Clearly, only a few species of fungi were present at the beginning of storage, which increased over days of storage owing to increased exposure of the stored sweet potato roots to different species of soil fungi. Among the three storage structures, the percentage occurrence of the various species of fungi differed in favor of the clamp storage structure.

\section{Conclusions}

The clamp storage structure showed the best form of storage in terms of low microbial infection of the sweet potato roots. Seven days of curing of sweet potato roots proved more effective than 14 days of curing. The microbes associated with deterioration of stored white variety sweet potato roots in traditional, pit, and clamp storage structures have been determined to help promote the adoption of the storage structures by the small-scale farmer. Further work is required on fungal and bacterial deterioration employing other varieties of sweet potato roots.

\section{References}

1. FAOSTAT. Food and Agriculture Organiz ation Database on Agriculture. http://agrifor.ac.uk/subject-listing/310.html, 2008, accessed 14/04/2010.

2. Low J, Lynam J, Lemaga B, et al. Sweet potato in Sub-Saharan Africa. In: Sweet potato. Part II. The Netherlands: Springer, 2009, pp. 359-90.

3. Hu W, Shun-ichiro T, Yoshiaki H. Effect of heat treatment on quality of sweet potato in wrapper-type cold storage during longterm storage. J Fac Agric Kyushu Univ 2004;49:129-38.

4. Hayma J. The storage of tropical agricul ture products. Agrodok 31. ACP/EEC, Wageningen, The Netherlands, 1982, p 73.

5. Boot RH. Post-harvest deterioration of tropical root crops: losses and their control. Trop Sci 1974;16:49-63.

6. Rees D, Van Oirschot QEA, Kapinga R. Sweet potato post-harvest assessment: experiences from East Africa. Natural Resources Institute, Chatham, UK, 2003, p 122.

7. Picha DH. Weight loss in sweet potatoes during curing and storage: contribution of transpiration and respiration. J Am Soc
Horticult Sci 1986;11:889-92.

8. Hall AJ, Devereau AD. Low-cost storage of fresh sweet potatoes in Uganda: lessons from participatory and on-station approaches to technology choice and adaptive testing. Outlook Agric 2000;29:275-82.

9. Van Oirschot QEA, Rees D, Aked J, et al. Cultivar variation in wound healing efficiency of sweet potato and Irish potato and effect on shelf-life. Presented at the International Society for Tropical Root Crops, Japan, 2000.

10. Demeaux M, Vivier P. Methodes moderns de conservation des ignames. L'Agronomie Tropicale 1984;39:184-91.

11. Thompson J. Storage and transport of fruit and vegetables in the West Indies. In: Proceedings of the Seminar/Workshop on Horticultural Development in the Caribbean, 12-15th March, Matarin, Venezuela. Tai EA, Phelps RH, Rankine LB, eds. Department of Crop Services, University of the West Indies, St. Augustine, Trinidad, 1972, pp 170-6.

12. Samson AR, Hoekstra ES, Frisvad CJ, et al. Introduction to food-borne fungi. Wageningen, The Netherlands: Posen and Looyen, 1995, p 322.

13. Atlas RM. Principles of microbiology. Mosby-Year Book, Inc. St Louis MO, 1995, pp 31-66.

14. Wills R, McGlasson B, Graham D, et al. Post-harvest: an introduction to the physiology and handling of fruit, vegetables and ornamentals. CAB International, Wallingford, UK, 1998, p 98.

15. Kushman LJ, Wright FS. Sweet potato storage. USDA Agriculture Handbook No, 1969 , p 358.

16. Lulai EC, Orr PH. Porometer measurements indicate wound severity and tuber maturity affects the early stages of woundhealing. Am Potato J 1995;72:225-41.

17. Rickard JE. Physiological deterioration in cassava roots. J Sci Food Agric 1985;36: 167-76.

18. Passam HC, Read SJ, Rickard JE. Wound repair in yam tubers: physiological processes during repair. New Phytol 1976;77:325-31.

19. Jenkins PD. Losses in sweet potato stored under traditional conditions in Bangladesh. Trop Sci 1982;24:17-28.

20. Centre for Overseas Pest Research. Pest control in tropical root crops. Pans Manual No 4, London, 1978, p 8. 